\title{
PERSPEKTIF AKUNTAN PUBLIK TENTANG KUALITAS LAPORAN KEUANGAN, INSENTIF BAGI MANAJEMEN, NILAI ETIS, DAN PENGENDALIAN INTERNAL DALAM MENYIKAPI PRAKTEK CREATIVE ACCOUNTING
}

\author{
F.X. Kurniawan Tjakrawala ${ }^{1}$ ), $\quad$ Metta Yuni $^{2}$ ) \\ 1) FE Universitas Tarumanagara, Jakarta, email: ktjakrawala@gmail.com \\ 2) KAP EY Indonesia, Jkt (afiliasi KAP Purwantono, Suherman, dan Surja)
}

\begin{abstract}
The purpose of this study is to obtain the empirical evidences that could predict the causal relationships occured from exogenous constructs such as financial report quality; perceived of management's incentives; ethical values; and internal control that may influence the endogenous construct, the public accountant's attitudes towards creative accounting practices. This study used primary data obtained through the field-survey method. The samples of this research subjects were taken by purposive sampling method applied through the distribution of 200 sets of questionnaires. The questionnaires addressed to the respondents who occupied in managerial level of the public accountant companies located at Jakarta, that listed on Indonesian Institute of CPA (IAPI) website and also Financial Service Authority (OJK) of capital market directory. The latent-path modeling applied to analyze the data of 70 units of valid questionnaires (usable response-rate was 35\%). The four hypotheses in this study were tested by implementing the technique of Partial Least Square-Structural Equation Modeling (PLS-SEM). The results of hypotheses testing statistically proved able to predict significantly that financial report quality; perceived of management's incentives; ethical values; and internal control positively influenced the public accountant's attitudes about creative accounting practices.
\end{abstract}

Keywords: Creative accounting practices, financial report quality, perceived of management's incentives, ethical values, pls-sem.

\begin{abstract}
Abstrak
Penelitia ini bertujuan mendapatkan bukti-bukti empiris guna mampu memprediksi hubungan kausal yang terjadi dari konstruk eksogen yaitu kualitas laporan keuangan, persepsi insentif bagi manajemen, nilai-nilai etis, serta pengendalian internal yang mempengaruhi konstruk endogen, sikap akuntan publik atas praktek creative accounting. Penelitian ini menggunakan data primer yang diperoleh melalui metode survey lapangan. Sampel penelitian diperoleh melalui metode purposive sampling dengan mendistribusikan 200 satuan kuesioner. Kuesioner tersebut dialamatkan kepada subyek penelitian yaitu para responden yang telah menduduki jenjang manajerial pada KAP yang berlokasi di Jakarta, yang terdaftar pada laman IAPI dan direktori OJK Pasar Modal. Penelitian ini menerapkan latent-path modeling untuk menganalisa data dari 70 satuan kuesioner yang memenuhi keabsahan (usable response-rate sebesar 35\%). Penelitian ini memuat empat hipotesis yang diuji dengan teknik Partial Least Square-Structural Equation Modeling (PLS-SEM). Hasil pengujian hipotesis secara statistik terbuktti mampu memprediksi bahwa konstruk-konstruk eksogen seperti kualitas laporan keuangan, persepsi insentif bagi manajemen, nilai-nilai etis, serta pengendalian internal secara signifikan berpengaruh positif terhadap konstruk endogen, sikap akuntan publik atas praktek creative accounting.
\end{abstract}

Kata kunci: Praktek creative accounting, kualitas laporan keuangan, persepsi insentif bagi manajemen, nilai-nilai etis, pls-sem. 


\section{PENDAHULUAN}

Skandal akuntansi maupun fraud selalu terjadi pada setiap era dan mungkin berlangsung hampir pada semua negara di dunia. Sejumlah kasus yang terjadi antara lain di Amerika Serikat (Adelphia Communication Corp., Bre-X Minerals, Enron Corp., Lehman Bros, Madoff Securities International Ltd., WorldCom, Inc., Xerox), Inggris (BCCI, Polly Peck), Swedia (ABB, Fermenta), Spanyol (Banesto, Bafinsa, Gescartera), Belanda (Fokker, Royal Ahold), Italia (A.C. Milan, Parmallat, Pirelli), Jepang (Fuji Sash, Kanebo, Nikko Cordial, Sanyo Special Steel), India (Apollo Tyres,

Hindustan Zync, Satyam), tentunya menambah kelam kisah skandal akuntansi dan fraud (Jones, 2011). Apabila mengambil contoh skala nasional, maka skandal akuntansi maupun fraud di Indonesia yang cukup menyita perhatian publik adalah kasus Kima Farma, kasus Bank Lippo, kasus Sarijaya Permana Sekuritas, kasus Katarina Utama.

Peran fungsi akuntansi demikian penting dan menjadi elemen sentral dari setiap kesuksesan maupun kegagalan bisnis, sehingga sangat penting dalam memahami skandal akuntansi yang terjadi. Fungsi akuntansi memampukan pelaku bisnis untuk menyelenggarakan seperangkat laporan yang akan memberi gambaran mengenai baikburuknya pengelolaan perusahaan kepada para pemangku kepentingan. Kendati

demikian, manakala aktivitas bisnis perusahaan cenderung memburuk, pihak manajemen perusahaan seringkali tergoda untuk menggunakan perangkat akuntansi demi menyamarkan kinerja aktual perusahaan dengan cara-cara yang tidak dapat dibenarkan (Jones, 2011). Hal ini dipertegas oleh Yadav (2013) yang mengungkapkan bahwa keberadaan celah/loopholes dari berbagai

regulasi dan/atau standar akuntansi memungkinkan pihak manajemen perusahaan menampilkan laporan keuangan yang tercitra secara baik melalui sejumlah praktek yang dikenal dengan sebutan creative accounting. Oleh sebab itu, manakala pihak manajemen perusahaan telah melakukan praktek creative accounting dengan mengeksploitasi celah regulasi di bidang akuntansi demi menampilkan kesan kinerja yang faktanya menyesatkan kepada para pemangku kepentingan, adalah menjadi tanggungjawab akuntan publik sebagai pihak yang memberikan assurans kepada pemangku kepentingan mengenai kewajaran laporan keuangan yang disusun oleh pihak manajemen/klien berdasarkan standar akuntansi dan tentu saja aspek profesionalitas yang dijunjung tinggi (Alexander dan Archer, 2003). Fakta empiris menunjukkan bahwa setidaknya selama dua dekade terakhir, investor; pemegang saham; dan kreditur mengalami kerugian dalam jumlah besar yang disebabkan karena ada keputusan yang telah diambil berdasarkan informasi keuangan yang disediakan dengan berbagai bentuk praktek creative accounting (Al Momani dan Obeidat, 2013).

Publikasi manca negara yang mengkaji sikap auditor terkait praktek creative accounting telah banyak dilakukan. Rabin (2005) dengan temuan bahwa evaluasi auditor atas kualitas laporan keuangan dan pengalaman auditor sebagai faktor yang berpengaruh terhadap sikap auditor atas creative accounting. Al Momani dan Obeidat (2013) dengan temuan bahwa kemampuan auditor untuk mendeteksi praktek creative accounting dipengaruhi oleh etika audit yang terdiri dari integritas, objektifitas, kompetensi profesional dan kehati-hatian, kerahasiaan dan perilaku profesional. Balaciu, et al. (2012) menemukan bahwa pengendalian internal mempunyai pengaruh terhadap sikap auditor atas creative accounting. Tasios dan Bekiaris (2012) menyatakan bahwa adanya pengaruh antara kualitas laporan keuangan berdasarkan karakteristik kualitatif laporan keuangan terhadap persepsi auditor. Selain

itu, Nassirzadeh, et al. (2012) mengemukakan bahwa ukuran perusahaan merupakan salah satu faktor penyebab terjadinya earning management.

Relatif sulitnya mendapatkan publikasi penelitian bidang pengauditas di Indonesia yang mengangkat isu tentang hubungan kausal antara financial report quality, perceived of management's incentives, ethical value, dan internal control terhadap sikap akuntan publik atas praktek creative accounting yang dilakukan oleh pihak klien, memotivasi berlangsungnya penelitian ini. 
Penelitian ini memiliki state of art dengan kebaharuan yang disajikan bagi kalangan peneliti bidang pengauditan dan/atau keperilakuan di Indonesia. Adapun rumusan masalah dan/atau pertanyaan penelitian yaitu: seberapa besar causal-predictive dari konstruk financial report quality, perceived of management's incentives, ethical value, dan internal control terhadap konstruk sikap akuntan publik atas praktek creative accounting yang dilakukan oleh pihak klien. Tujuan penelitian ini adalah: memperoleh bukti empiris guna memprediksi hubungan kausal yang terjadi dari konstruk financial report quality, perceived of management's incentives, ethical value, dan internal control terhadap konstruk sikap akuntan publik atas praktek creative accounting yang dilakukan oleh pihak klien.

\section{KAJIAN LITERATUR}

\section{Agency Theory}

Teori ini menyatakan bahwa berbagai konflik dapat timbul dalam setiap bentuk hubungan koperatif manakala satu pihak (principal) melakukan kontrak dengan pihak lain (agent) untuk membuat keputusan mewakili kepentingan sang principal (Jensen dan Meckling, 1976). Sejatinya permasalahan berpijak dari terpisahnya aspek kepemilikan dengan aspek pengendalian. Bentuk pendelegasian wewenang dan tanggungjawab dari principal terhadap agent berimbas pada ketidaksepadanan insentif yang disebabkan oleh perbedaan preferensi dari kedua pihak mengenai resiko. Lubatkin, et al.(2005) menegaskan bahwa konflik keagenan terjadi sebagai akibat dari asimetri informasi antara

pihak manajemen dan para pemangku kepenttingan lainnya.

Relevansi agency theory terhadap praktek creative accounting tertuju pada perspektif informasional yang menjadi elemen kunci yang mendasari studi mengenai fenomena praktek creative accounting. Perspektif informasional mengasumsikan

bahwa laporan akuntansi memiliki kandungan informasi dan memiliki nilai bagi

para pemangku kepentingan dalam menyajikan sinyal-sinyal yang bermanfaat. Oleh karenanya pihak penyusun laporan (agent) seyogyanya menyiapkan laporan keuangan yang menggambarkan berbagai hal secara benar dan jujur berdasarkan prinsip, kebijakan, maupun standar yang berlaku (Lubatkin, et al. 2005).

\section{Stakeholder Theory}

Stakeholder theory pertama kali diperkenalkan oleh R. Edward Freeman pada tahun 1984 (Laplume, et al. 2008). Teori ini berpusat pada isue-isue di seputar pemangku kepentingan dalam institusi. Teori ini menetapkan bahwa entitas perusahaan selalu berusaha untuk memberikan keseimbangan bagi para pemangku kepentingan kepentingan yang beragam guna memastikan bahwa setiap pihak memperoleh suatu tingkat kepuasan tertentu (Salome, et al. 2012). Bowen, et al. (1992) memakai stakeholder theory untuk menjabarkan saat yang tepat untuk mengumumkan laba. Dan temuan mereka menyatakan bahwa waktu yang tepat dalam mengumumkan laba akan mempengaruhi persepsi para pemangku kepentingan untuk menilai kinerja perusahaan.

Richardson (2000) mengkaji stakeholder theory dari aspek asimetri

informasi. Manakala asimetri informasi antara perusahaan dan pemangku kepentingan demikian tinggi, maka pemangku kepentingan tidak memiliki sumber daya yang memadai untuk memonitor perilaku manajer, yang dapat menyebabkan manajer untuk melaksanakan praktek manajemen laba. Hasil penelitiannya mendukung hubungan antara manajemen laba dan tingkat asimetri informasi. Hasil tersebut selaras dengan temuan Winston dan Sharp (2005). Relevansi stakeholder theory terhadap praktek creative accounting tercermin pada penerapan pengetahuan akuntansi untuk memanipulasi angka-angka yang dilaporkan, dengan tetap berada dalam koridor regulasi. Hal ini sejatinya menunjukkan bahwa praktek creative accounting mencerminkan apa yang ingin disampaikan pihak manajemen kepada para pemangku kepentingan, dan tidak menampilkan kinerja perusahaan yang sebenarnya (Yadav, 2013).

\section{Creative Accounting}

Istilah creative accounting banyak digunakan di Inggris, dan dikenal dengan sebutan earnings management di Amerika 
Serikat. Istilah lain yang juga sering dipakai adalah aggressive; innovative; cosmetic; deceptive accounting (Idris, et al. 2012). Creative accounting mengacu pada setiap langkah yang digunakan untuk memainkan angka-angka keuangan, termasuk pilihan dan penerapan prinsip akuntansi agresif, penipuan pelaporan keuangan, dan setiap langkah yang diambil melalui earning management atau income smoothing (Mulford dan Comiskey, 2002). Yadav (2013) memberi pengertian

creative accounting sebagai praktek akuntansi yang mungkin ataupun tidak mengikuti aturan praktek standar akuntansi tetapi tentu menyimpang dari aturan-aturan dan regulasi. Ini mungkin ditandai dengan kompleksitas penggunaan cara-cara inovatif untuk mengkarakterisasi pendapatan, aset dan kewajiban. Creative accounting menjadi istilah yang dipakai karena misrepresentasi berlangsung secara sistematis pada saat melaporkan pendapatan, kewajiban dan aset perusahaan/organisasi yang seyogyanya dilaporkan dengan benar dan jujur.

Vladu dan Matis (2010) memaknai creative accounting sebagai piranti yang digunakan oleh manajemen perusahaan untuk beradaptasi, berkembang dan menjadi lebih kompetitif dalam turbulensi lingkungan bisnis di mana perusahaan beroperasi, beradaptasi, yang membutuhkan profesional

yang sangat adaptif dan mampu menghasilkan ide-ide kreatif. Manajemen perusahaan senantiasa memanfaatkan grey area berupa celah/loopholes dalam suatu aturan tertentu yang memungkinkan praktek akuntansi tertentu dan tidak dilarang oleh regulator. Vladu dan Matis (2010) menegaskan bahwa pemahaman mengenai creative accounting terpisah ke dalam dua kubu. Ada kubu yang memandang praktek creative accounting secara positif, namun ada pula kubu yang memandangnya secara negatif karena dianggap tidak etis. Yadav (2013) menyatakan bahwa praktek creative accounting bukanlah suatu tindakan fraud namun merupakan kecerdikan dari pihak manajemen mengambil manfaat dari celah dalam standar/peraturan akuntansi. Hal ini tidak bisa dikatakan fraud karena praktek creative accounting berlangsung secara legal. Hal ini tercantum pada sejumlah opsi yang tersedia dalam standar akuntansi, seperti: metode berbeda yang tersedia untuk penyusutan dan estimasi masa manfaat aset; pilihan yang tersedia dalam pengakuan pendapatan maupun kerugian, metode berbeda yang tersedia dalam menilai persediaan (LIFO atau FIFO).

Hubungan kausal dari Financial Report Quality, Perceived of Management's Incentives, Ethical Value, Internal Control terhadap Praktek Creative Accounting

Konstruk financial report quality pada penelitian ini mengacu pada persepsi auditor tentang karakteristik kualitatif yang seyogyanya ada pada setiap laporan keluaran (yang dirilis oleh pihak klien). IASB (2013) menyatakan bahwa laporan keuangan memberikan informasi tentang sumber daya entitas pelapor ekonomi, klaim terhadap entitas pelaporan dan efek dari transaksi dan peristiwa dan kondisi lain yang mengubah

sumberdaya. Karakteristik kualitatif informasi keuangan yang berguna berlaku untuk informasi keuangan yang disediakan dalam laporan keuangan, serta informasi keuangan yang disediakan dengan cara lain. Biaya menjadi faktor kendala melekat terhadap kemampuan entitas pelapor untuk memberikan informasi keuangan yang berguna. Namun, pertimbangan dalam menerapkan karakteristik kualitatif dan kendala biaya mungkin saja berbeda sesuai dengan jenis informasi. Agar berguna maka informasi keuangan harus relevan dan secara jujur menyajikan apa yang seharusnya. Kegunaan laporan keuangan akan semakin baik bila memenuhi kondisi comparable; verifiable; timely; understandable. IAASB (2015) menegaskan melalui ISA 700 yang mensyaratkan akuntan publik mengevaluasi apakah laporan keuangan disusun dan disajikan, dalam semua hal yang material,

sesuai dengan persyaratan kerangka pelaporan keuangan yang berlaku. Evaluasi ini mencakup pertimbangan aspek kualitatif praktekakuntansi entitas, termasuk indikator kemungkinan bias dalam penilaian manajemen, yang dapat dipengaruhi oleh pemahaman akuntan publik mengenai alasan pihak manajemen untuk tidak membuat koreksi. Sejumlah hasil penelitian yang telah dilakukan oleh Rabin (2005), Olagunju (2011), maupun Tasios dan Bekiaris (2012) 
menunjukkan hasil yang konsisten bahwa terdapat hubungan kausal yang berlangsung secara positif dan signifikan dari persepsi auditor mengenai financial report quality terhadap sikap auditor atas praktek creative accounting yang dilakukan oleh klien.

Konstruk perceived of management's incentives pada penelitian ini berkenaan dengan persepsi akuntan publik mengenai sejumlah faktor yang yang mempengaruhi pihak manajemen melakukan praktek creative accounting demi mendapatkan insentif tertentu sebagai imbas dari upaya mengejar target jangka pendek (Rabin, 2005). Jones (2011) menyatakan bahwa terdapat sejumlah faktor yang mempengaruhi berlangsungnya praktek creative accounting, berupa insentif personal (seperti: peningkatan kompensasi/gaji; bonus; opsi saham), pemenuhan ekspektasi pasar; kondisi-kondisi khusus (seperti: merjer dan akuisisi; justifikasi), upaya menyamarkan suatu kecurangan. Salah satu insentif yang paling umum adalah paket remunerasi manajer. Dalam praktek bisnis secara umum, manajer berhak untuk bonus uang tunai atau opsi saham atas pencapaian laba dalam laporan keuangan. Hal ini umumnya terdapat dalam setiap kontrak kerja manajemen mengenai peluang kompensasi berupa peningkatan gaji tahnan, bonus, evaluasi kinerja, dan paket kompensasi yang seiring dengan pencapaian target (Singh, 2008 dalam Rani, et al. 2013). Hasil penelitian Matsumoto (2002) dan Nassirzadeh, et al. (2012) secara konsisten menunjukkan bahwa terdapat hubungan kausal yang berlangsung secara positif dan signifikan dari persepsi auditor mengenai

management's incentives dalam memanipulasi laba terhadap sikap auditor atas praktek creative accounting yang dilakukan oleh klien. Namun hasil tersebut tidak konsiten dengan penelitian Rabin (2005).

Kontruk ethical value dalam penelitian ini berkenaan dengan persepsi akuntan publik terhadap nilai-nilai etis yang patut dijunjung demi menjaga profesionalitas pada setiap penugasan audit. Arens, et al. (2012) mendefinisikan etika sebagai seperangkat prinsip moral atau nilai-nilai yang dapat berupa hukum dan peraturan, doktrin gereja, kode etik bisnis untuk kelompok profesional dan kode etik dalam organisasi. Ethical value diperlukan untuk masyarakat guna berlaku secara tertib. Ethical value merekatkan segenap lapisan masyarakat secara bersamasama. Arens, et al. (2012) juga menyatakan bahwa terdapat sejumlah ethical value yang mengaitkan dengan perilaku etis yang

meliputi: trustworthiness, respect, responsibility, caring, citizenship. Menurut Rabin (2005) penilaian etis akuntan publik dibentuk oleh ketentuan-ketentuan kode etik, kebijakan organisasi yang mengatur etika dan moral individu. Ethical value menjadi dasar untuk akuntan publik dalam memberikan opini audit. Hasil penelitian Elias (2002), Gul, et al. (2003), serta Wier (2008) secara konsisten menunjukkan bahwa terdapat hubungan kausal yang berlangsung secara positif dan signifikan antara persepsi auditor mengenai ethical values terhadap sikap auditor atas praktek creative accounting yang dilakukan oleh klien. Akan tetapi hasil tesebut tidak konsisten dengan penelitian yang dilakukan oleh Rabin (2005), Bennie dan Pflugrath (2009), maupun Al Momani dan Obeidat (2013).

Konstruk internal control dalam penelitian ini berkenaan dengan persepsi akuntan publik tentang internal control yang khususnya berlangsung pada pihak klien. Arens, et al. (2012) menyatakan bahwa pengendalian intern merupakan suatu sistem yang terdiri dari kebijakan dan prosedur yang dirancang untuk memberikan jaminan yang wajar bahwa perusahaan mencapai tujuan dan sasaran. Kebijakan dan prosedur ini sering disebut pengendalian, dan secara kolektif membentuk pengendalian internal entitas. Pihak manajemen umumnya merancang sebuah sistem pengendalian internal yang efektif demi mencapai tujuan berupa keandalan pelaporan keuangan, efisiensi dan efektivitas operasi, kepatuhan terhadap hukum dan peraturan. Fokus akuntan publik

ditujukan pada keandalan pelaporan keuangan dan kepatuhan terhadap hukum dan peraturan yang secara material dapat mempengaruhi pelaporan keuangan. Hasil penelitian Arel, et al. (2006), O'Leary, et al. (2006), Balaciu, et al. (2012), secara konsisten menunjukkan bahwa terdapat hubungan kausal yang berlangsung secara positif dan signifikan dari persepsi auditor 
mengenai internal control terhadap sikap auditor atas praktek creative accounting yang dilakukan oleh klien. Kendati demikian, hasil penelitian mereka tidak konsisten dengan penelitian yang dilakukan oleh Al Sawalqa dan Qtish (2012).

Berdasarkan kajian teori yang telah disajikan, maka hipotesis yang diajukan dalam penelitian ini-sebagaimana ditampilkan melalui Model Penelitian pada Gambar 1-adalah sebagai berikut:

H1. Perspektif akuntan publik tentang financial report quality berpengaruh positif terhadap sikap akuntan publik atas praktek creative accounting yang dilakukan oleh pihak klien.
H2. Perspektif akuntan publik tentang management's incentives dalam memanipulasi laba berpengaruh positif terhadap sikap akuntan publik atas praktek creative accounting yang dilakukan oleh pihak klien.

H3. Perspektif akuntan publik tentang ethical values berpengaruh positif terhadap sikap akuntan publik atas praktek creative accounting yang dilakukan oleh pihak klien.

H4. Perspektif akuntan publik tentang internal control berpengaruh positif terhadap sikap akuntan publik atas praktek creative accounting yang dilakukan oleh pihak klien.

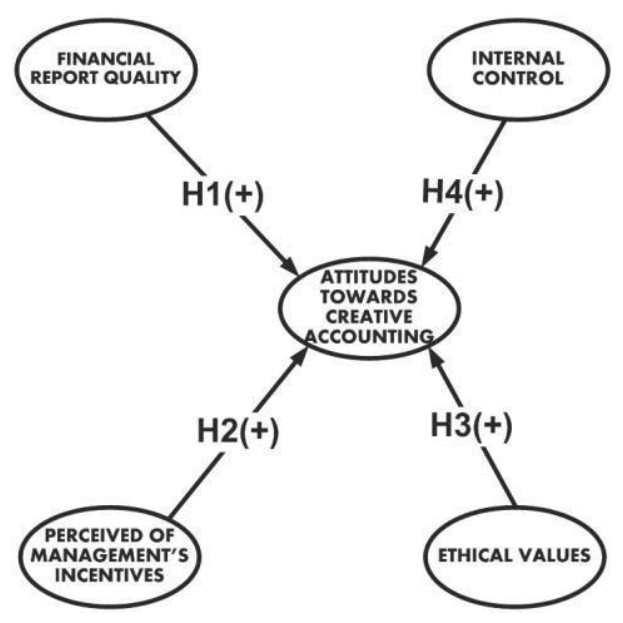

Gambar 1.

Model Penelitian

\section{METODE PENELITIAN}

\section{Desain Penelitian dan Teknik Sampling}

Jenis data yang digunakan dalam

penelitian ini adalah data primer, yang didapatkan melalui metode survey. Unit of analysis dalam penelitian ini adalah orang. Populasi dari subyek penelitian ini adalah para akuntan publik yang telah menduduki jenjang manajerial pada KAP di Jakarta. Pemilihan sampel berlangsung dengan teknik purposive sampling. Adapun kriteria penarikan sampel yang menjadi subyek penelitian ini yaitu: a) responden berada pada jabatan supervisor, manajer, dan partner; b) responden bekerja pada KAP yang berlokasi di Jakarta; c) responden bekerja pada KAP yang terdaftar di laman IAPI; d) responden bekerja pada KAP yang akuntannya terdaftar pada direktori OJK Pasar Modal.

Penelitian ini menggunakan indikator refleksif yaitu indikator yang dianggap merepresentasikan konstruk/ variabel laten (Ghozali, 2011). Adapun jumlah sampel yang seyogyanya diperoleh pada penelitian yang menerapkan indikator refleksif yaitu minimal lima hingga 10 kali jumlah indikatornya

(Ferdinand, 2014). Dengan mempertimbangkan jumlah seluruh indikator refleksif dalam penelitian yang berjumlah 36 , maka ditetapkanlah jumlah sampel yang memenuhi ataupun melebihi batas minimal yaitu sebanyak 200 responden yang dikirimi angket kuesioner melalui pos dan email. 


\section{Operasionalisasi dan Pengukuran Konstruk}

Indikator refleksif dipakai untuk menjelaskan konstruk eksogen maupun endogen. Indikator refleksif dalam penelitian ini diukur melalui instrumen Skala Likert dengan rentang satu hingga lima, dimana angka $1=$ Sangat Tidak Setuju; $2=$ Tidak Setuju; 3= Netral; 4= Setuju; 5= Sangat Setuju. Penelitian ini memposisikan skala Likert ke dalam kategori Skala Interval dengan merujuk pada Hair, et al. (2014); Jogiyanto (2010), McBride (2010); maupun Vander stoep \& Johnston (2009).

Dalam menentukan item-item indikator refleksif atas konstruk eksogen maupun endogen, penelitian ini mengacu pada hasil penelitian Al Momani dan Obeidat (2013); Tasios dan Bekiaris (2012); Balaciu, et al.
(2012); serta Rabin (2005). Penelitian ini memuat empat konstruk eksogen yaitu Financial Report Quality (FRQU) yang direpresentasikan melalui tujuh indikator refleksif; Perceived of Management's Incentives (POMI) yang direpresentasikan dengan sembilan indikator refleksif; Ethical Value (ETVA) yang direpresentasikan dengan delapan indikator refleksif; dan

Internal Control (INCO) yang direpresentasikan dengan empat indikator refleksif. Penelitian ini hanya memuat sebuah konstruk endogen yaitu sikap akuntan publik atas praktek Creative Accounting (CRAT) yang direpresentasikan melalui delapan indikator refleksif. Operasionalisasi konstruk dan indikator dalam penelitian ini

ditampilkan pada Tabel

1.

Tabel 1

Tabulasi Operasionalisasi Konstruk-Indikator Refleksif

\begin{tabular}{|c|c|c|}
\hline Konstruk & Kode & Indikator Refleksif \\
\hline \multirow{8}{*}{$\begin{array}{l}\text { FINANCIAL } \\
\text { REPORT QUALITY } \\
\text { (FRQU)_Konstruk } \\
\text { Eksogen } \\
\text { Indikator refleksif } \\
\text { merujuk pada Tasios } \\
\text { dan Bekiaris } \\
\text { (2012) }\end{array}$} & FRQU1 & $\begin{array}{l}\text { Laporan keuangan yang disusun oleh manajemen klien } \\
\text { memberikan manfaat atas perkembangan prediksi masa depan } \\
\text { yang dilakukan oleh pemakai laporan keuangan }\end{array}$ \\
\hline & FRQU2 & $\begin{array}{l}\text { Laporan keuangan memberikan umpan balik kepada para } \\
\text { pemakai laporan keuangan mengenai bagaimana berbagai }\end{array}$ \\
\hline & & $\begin{array}{l}\text { peristiwa dan transaksi signifikan yang terjadi mempengaruhi } \\
\text { perusahaan }\end{array}$ \\
\hline & FRQU3 & $\begin{array}{l}\text { Informasi non keuangan mengenai peluang dan risiko bisnis } \\
\text { bermanfaat untuk melengkapi informasi yang terdapat dalam } \\
\text { laporan keuangan }\end{array}$ \\
\hline & FRQU4 & $\begin{array}{l}\text { Laporan keuangan menyajikan pembuktian yang cukup dan } \\
\text { valid mengenai asumsi dan estimasi yang digunakan (seperti } \\
\text { laporan aktuaria, penilaian,dll) }\end{array}$ \\
\hline & FRQU5 & $\begin{array}{l}\text { Laporan keuangan menyediakan informasi yang dapat } \\
\text { dibandingkan dengan informasi yang disediakan oleh organisasi } \\
\text { lain dalam industri yang sama }\end{array}$ \\
\hline & FRQU6 & $\begin{array}{l}\text { Catatan atas laporan keuangan memberikan informasi yang jelas } \\
\text { dan dapat dimengerti }\end{array}$ \\
\hline & FRQU7 & $\begin{array}{l}\text { Laporan keuangan menyajikan kerugian penurunan nilai asset } \\
\text { (impairment loss on asset) }\end{array}$ \\
\hline \multirow{3}{*}{$\begin{array}{l}\text { PERCEIVED OF } \\
\text { MANAGEMENT'S } \\
\text { INCENTIVES } \\
\text { (POMI)_Konstruk } \\
\text { Eksogen }\end{array}$} & POMI1 & Mencapai ekspektasi laba yang dibuat oleh analis \\
\hline & POMI2 & $\begin{array}{l}\text { Mencapai perkiraan pendapatan yang diramalkan oleh direktur } \\
\text { perusahaan }\end{array}$ \\
\hline & POMI3 & $\begin{array}{l}\text { Bonus yang diberikan kepada manajer berdasarkan keuntungan } \\
\text { yang diperoleh }\end{array}$ \\
\hline \multirow{6}{*}{$\begin{array}{l}\text { Indikator refleksif } \\
\text { merujuk pada Rabin } \\
(2005)\end{array}$} & POMI4 & $\begin{array}{l}\text { Menghindari pelaporan kerugian atau pertumbuhan bisnis yang } \\
\text { lambat }\end{array}$ \\
\hline & POMI5 & Perusahaan memiliki perjanjian hutang \\
\hline & POMI6 & Perusahaan mengalami kerugian yang terus-menerus \\
\hline & POMI7 & Tidak adanya komite audit \\
\hline & POMI8 & Dewan direksi didominasi oleh manajemen puncak \\
\hline & POMI9 & Kepemilikan institusional yang tinggi \\
\hline
\end{tabular}




\begin{tabular}{|c|c|c|}
\hline Konstruk & Kode & Indikator Refleksif \\
\hline $\begin{array}{l}\text { ETHICAL VALUE } \\
\text { (ETVA)_Konstruk }\end{array}$ & ETVA1 & $\begin{array}{l}\text { Akuntan publik telah bersikap independen ketika melaksanakan } \\
\text { jasa profesional seperti yang ditetapkan oleh standar audit }\end{array}$ \\
\hline Eksogen & ETVA2 & $\begin{array}{l}\text { Akuntan publik yakin bahwa pemakai informasi keuangan } \\
\text { percaya bahwa akuntan publik telah bersikap independen }\end{array}$ \\
\hline $\begin{array}{l}\text { Indikator refleksif } \\
\text { merujuk pada } \mathrm{Al}\end{array}$ & ETVA3 & $\begin{array}{l}\text { Akuntan publik memiliki sudut pandang objektif ketika } \\
\text { mengeluarkan laporan audit }\end{array}$ \\
\hline \multirow[t]{5}{*}{$\begin{array}{l}\text { Momani dan Obeidat } \\
\text { (2013) }\end{array}$} & ETVA4 & $\begin{array}{l}\text { Akuntan publik tidak melakukan kegiatan audit untuk klien } \\
\text { dimana akuntan publik merupakan seorang direktur, pejabat, } \\
\text { manajer, atau karyawan di perusahaan klien tersebut }\end{array}$ \\
\hline & ETVA5 & $\begin{array}{l}\text { Akuntan publik tidak menerima untuk mengaudit laporan klien } \\
\text { ketika memiliki kepemilikan saham di perusahaan klien }\end{array}$ \\
\hline & ETVA6 & $\begin{array}{l}\text { Ketika dalam praktek, tidak berusaha untuk memperoleh klien } \\
\text { dengan iklan dan bentuk lain yang tidak diinginkan dengan cara } \\
\text { yang salah }\end{array}$ \\
\hline & ETVA7 & $\begin{array}{l}\text { Ketika dalam praktek, akuntan publik tidak menerima atau } \\
\text { membayar komisi atau fee referensi untuk setiap klien }\end{array}$ \\
\hline & ETVA8 & $\begin{array}{l}\text { Akuntan publik bebas dari konflik kepentingan dalam } \\
\text { melaksanakan tanggung jawab profesional }\end{array}$ \\
\hline $\begin{array}{l}\text { INTERNAL } \\
\text { CONTROL (INCO) } \\
\text {-Konstruk }\end{array}$ & INCO1 & $\begin{array}{l}\text { Pengendalian internal yang memadai dapat mengurangi } \\
\text { kecenderungan manajemen menggunakan praktek creative } \\
\text { accounting }\end{array}$ \\
\hline Indikator refleksif & INCO2 & $\begin{array}{l}\text { Praktek maksimalisasi atau minimalisasi keuntungan terjadi } \\
\text { karena disebabkan oleh pengendalian internal yang kurang } \\
\text { memadai }\end{array}$ \\
\hline \multirow{2}{*}{$\begin{array}{l}\text { Indikator refleksif } \\
\text { merujuk pada } \\
\text { Balaciu, et al. (2012) }\end{array}$} & INCO3 & $\begin{array}{l}\text { Praktek mencatat beban periode sebelumnya sebagai beban } \\
\text { periode saat ini terjadi karena pengendalian internal yang } \\
\text { kurang memadai }\end{array}$ \\
\hline & INCO4 & $\begin{array}{l}\text { Praktek mencatat pendapatan periode sebelumnya sebagai } \\
\text { pendapatan periode saat ini terjadi karena pengendalian internal } \\
\text { yang kurang memadai }\end{array}$ \\
\hline $\begin{array}{l}\text { ATTITUDES } \\
\text { TOWARDS } \\
\text { CREATIVE } \\
\text { ACCOUNTING }\end{array}$ & CRAT1 & $\begin{array}{l}\text { Akuntan publik mampu mendeteksi penjualan aset dengan harga } \\
\text { yang lebih tinggi dari nilai bukunya dalam periode tertentu } \\
\text { dilakukan hanya untuk mempengaruhi keuntungan klien } \\
\text { (perusahaan) }\end{array}$ \\
\hline $\begin{array}{l}\text { (CRAT)-Konstruk } \\
\text { Endogen }\end{array}$ & CRAT2 & $\begin{array}{l}\text { Akuntan publik mampu mendeteksi adanya transaksi dan jurnal } \\
\text { fiktif untuk mempengaruhi keuntungan dalam periode akuntansi } \\
\text { yang dipilih }\end{array}$ \\
\hline $\begin{array}{l}\text { Indikator refleksif } \\
\text { merujuk pada } \mathrm{Al}\end{array}$ & CRAT3 & $\begin{array}{l}\text { Akuntan publik mampu mengidentifikasi transfer keuntungan } \\
\text { dari satu periode ke periode yang lain }\end{array}$ \\
\hline \multirow[t]{5}{*}{$\begin{array}{l}\text { Momani dan Obeidat } \\
\text { (2013) }\end{array}$} & CRAT4 & $\begin{array}{l}\text { Akuntan publik merasa bahwa manajemen memiliki insentif } \\
\text { untuk melakukan creative accounting }\end{array}$ \\
\hline & CRAT5 & $\begin{array}{l}\text { Akuntan publik memiliki kemampuan untuk mendeteksi } \\
\text { pemilihan metode akuntansi yang dipilih untuk memaksimalkan } \\
\text { keuntungan }\end{array}$ \\
\hline & CRAT6 & $\begin{array}{l}\text { Akuntan publik dapat mendeteksi perubahan dalam metode } \\
\text { akuntansi yang digunakan atas investasi jangka panjang }\end{array}$ \\
\hline & CRAT7 & $\begin{array}{l}\text { Akuntan publik dapat mendeteksi jika manajemen tidak } \\
\text { melakukan pencatatan atas penurunan nilai aset }\end{array}$ \\
\hline & CRAT8 & $\begin{array}{l}\text { Akuntan publik memiliki kemampuan untuk mendeteksi } \\
\text { terjadinya creative accounting yang digunakan untuk } \\
\text { mengkapitalisasi beban-beban yang tidak boleh dikapitalisasi }\end{array}$ \\
\hline
\end{tabular}




\section{Teknik Pengolahan Data dan Pengujian Hipotesis.}

Paparan statistik deskriptif

karakteristik subyek peneilitian ditujukan untuk memberikan gambaran mengenai karalteristik demografi responden yang meliputi usia, masa kerja, jenis kelamin, jabatan, serta jenjang pendidikan. Paparan statistik deskriptif menggunakan aplikasi software SPSS $^{\circledR}$ v.21. Penelitian ini menerapkan latent-path modeling yang akan dianalsis dengan metode Partial Least Square-Structural Equation Modeling (PLSSEM). Metode PLS-SEM cocok untuk

causal-predictive analysis dan tidak mensyaratkan uji normalitas (Ghozali, 2011). Pengolahan data untuk keperluan pengujian model penelitian (dan hipotesis) dilakukan dengan aplikasi SmartPls $^{\circledR}$ v.2. Aplikasi tersebut memiliki tiga menu utama yaitu menu PLS Algoritma; Bootstrapping; dan Blindfolding. Pengujian model penelitian dengan teknik PLS-SEM berlangsung melalui dua tahap yaitu Uji Model Pengukuran (Outer Model Test) dan Uji Model Struktural (Inner Model Test).

Outer Model Test berlangsung dengan menggunakan menu PLS Algoritma serta menu bootstrapping dan akan menguji kualitas data berupa uji validitas dan uji reliabilitas. Uji Validitas menggunakan kriteria Convergent Validity, dimana

indikator refleksif dianggap valid menjelaskan suatu konstruk jika memiliki nilai loading-factor lebih besar dari 0,50, kendati ambang nilai idealnya adalah 0,70. Disamping Convergent Validity, juga terdapat kriteria Discriminant Validity dengan mengamati besaran nilai AVE/Average Variance Extracted dengan ambang nilai lebih besar dari 0,50 (Ghozali, 2011). Adapun Uji Reliabilitas berlangsung dengan menggunakan kriteria Composite Reliability, dimana suatu kontruk dikatakan bernilai baik bila nilai Composite Reliability lebih besar atau sama dengan 0,70 (Ghozali 2011).

Inner Model Test, menurut Hair, et al. (2014) dievaluasi dengan mengamati nilai Koefisien Determinasi $/ \mathrm{R}^{2}$ (ambang nilai 0,75; 0,$50 ; \quad 0,25 \quad$ yang masing-masing mengindikasikan bahwa proporsi varians konstruk endogen yang dapat dijelaskan oleh konstruk eksogen bersifat substansial, moderat, lemah). Nilai Koefisien Determinasi $/ \mathrm{R}^{2}$ ditampilkan dalam menu PLS Algoritma dari aplikasi SmartPls ${ }^{\circledR}$ v.2. Inner model test juga akan menguji $\mathrm{F}^{2}$ atau effect size (dengan ambang nilai 0,$35 ; 0,15$; 0,02 yang masing-masing mengindikasikan bahwa konstruk eksogen memiliki effect besar, medium, kecil terhadap konstruk endogen). $\quad F^{2}$ adalah suatu ukuran untuk menilai besarnya dampak relatif dari konstruk eksogen terhadap konstruk endogen (Hair, et al. 2014). Nilai $\mathrm{F}^{2}$ effect size ditampilkan melalui menu blindfolding. Pengukuran $\mathrm{F}^{2}$ menggunakan formula sebagai berikut:

$\mathbf{F}^{2}$

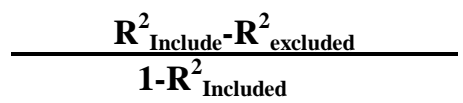

$$
1-R_{\text {Included }}^{2}
$$

merupakan nilai $\mathrm{R}^{2}$ dari konstruk endogen manakala suatu konstruk eksogen

diikutsertakan dalam model. merupakan nilai $\mathrm{R}^{2}$ dari konstruk endogen manakala suatu konstruk eksogen dikeluarkan dari model (Hair, et al. 2014).

Inner model test juga akan mengukur Stone-Geisser's $\boldsymbol{Q}^{2}$ value yang digunakan untuk menilai relevansi prediktif konstruk eksogen terhadap suatu konstruk endogen. Formula untuk mengukur Stone-Geisser's $\boldsymbol{Q}^{2}$ value adalah sebagai berikut:

Q2 = 1 - Sum of the square Prediction Error (SSE) Sum of the square Observation Error (SSO) Stone-Geisser's $\mathrm{Q}^{2}$ value pada inner model test diperoleh melalui fungsi menu Blindfolding dari aplikasi SmartPLS ${ }^{\circledR}-\mathrm{v} .2$, yang ditunjukkan oleh nilai estimasi dari

Construct Crossvalidated Redundancy. Ambang nilai untuk $\mathrm{Q}^{2}$ adalah lebih besar dari nol untuk menyatakan bahwa terdapat relevansi prediktif dari konstruk eksogen terhadap konstruk endogen (Hair, et al. 2014).

Adapun pengujian hipotesis dilakukan melalui uji signifikansi t-statistik atas nilai path coefficient yang diperoleh pada inner model test. Path coefficient mencerminkan pola asosiasi kausal prediktif antar konstruk terkait (Ghozali, 2011). Nilai path coefficient ditampilkan oleh menu PLS Algoritma. Hasil uji signifikansi t-statistik akan ditampilkan oleh menu Bootstrapping. 
Penelitian ini merujuk pada Ghozali (2011) dalam menetapkan ambang nilai tingkat signifikansi t-statistik yaitu lebih besar dari ttabel/1,64 (p-value lebih kecil dari 0,10); lebih besar dari t-tabel/1.96 ( $p$-value lebih kecil dari 0,05); atau lebih besar dari ttabel/2.58 ( $p$-value lebih kecil dari 0,01). Model persamaan struktural penelitian ini dapat dinyatakan sebagai berikut:

CRAT $=\gamma_{1.1}$ FRQU $+\gamma_{1.2}$ POMI $+\gamma_{1.3}$ ETVA $+\gamma_{1.4} \mathrm{INCO}+\zeta$

Model persamaan struktural tersebut menampilkan $\gamma$ yang mencerminkan nilai path coefficient antara variabel laten eksogen (FRQU; POMI; ETVA; dan INCO) dengan variabel laten endogen (CRAT). Sedangkan $\zeta$ mencerminkan variabel residual atau kesalahan pengukuran.

\section{HASIL DAN PEMBAHASAN}

\section{Hasil Statistik Deskriptif Responden Penelitian}

Kuesioner yang diidtribusikan kepada responden dalam penelitian ini berjumlah 200 satuan. Sebanyak 86 satuan kuesioner berhasil diperoleh kembali dari para responden, namun hanya sejumlah 70 satuan kuesioner yang terisi lengkap dan dapat diolah. Dengan demikian usable response-rate sebesar 35\%. Tabulasi dari output $\operatorname{SPSS}^{\circledR} \quad$ v.21 menyajikan karakteristik responden mengenai data jenis kelamin; strata pendidikan; posisi/jabatan; rentang usia; serta masa kerja, dalam penelitian ini dipaparkan pada Tabel 2

Tabel 2

Tabulasi Statistik Deskriptif Responden

\begin{tabular}{llrrlrrr}
\hline Karakteristik Responden & Freq. & Percent & Karakteristik Responden & Freq. & Percent \\
\hline Jenis & Laki-laki & 41 & $58,57 \%$ & Rentang & & & \\
Kelamin & Perempuan & 29 & $41,43 \%$ & Usia & $21-30$ & 23 & $32,86 \%$ \\
& Total & 70 & $100,00 \%$ & $31-40$ & 30 & $42,86 \%$ \\
& Strata & 33 & $47,14 \%$ & $>40$ & 17 & $24,28 \%$ \\
Pendidikan & S2 & 37 & $52,86 \%$ & Total & 70 & $100,00 \%$ \\
& Total & 70 & $100,00 \%$ & Masa Kerja & & \\
& Supervisor & 25 & $35,71 \%$ & & $\leq 5$ tahun & 18 & $25,71 \%$ \\
Jabisi/ & Manajer & 36 & $51,43 \%$ & $6-10$ tahun & 38 & $54,29 \%$ \\
& Partner & 9 & $12,86 \%$ & $>10$ tahun & 14 & $20,00 \%$ \\
& Total & 70 & $100,00 \%$ & Total & 70 & $100,00 \%$ \\
\hline
\end{tabular}

\section{Hasil Uji Model Pengukuran (Outer Model Test)}

Outer Model Test dilaksanakan melalui uji kualitas data yaitu berupa uji validitas dan uji reliabilitas. Hasil uji validitas melalui nilai convergent validity olahan menu PLS algoritma dari aplikasi SmartPls $^{\circledR}$ v.2 tercermin pada nilai loading-factor dari 36 indikator refleksif (FRQU1,FRQU2,..,hingga CRAT6). Seluruh nilai loading-factor indikator refleksif dari keempat konstruk menunjukkan hasil lebih besar dari ambang nilai 0,50 . Dengan demikian semua indikator refleksif atas konstruk FRQU, POMI, ETVA, INCO dan CRAT telah memiliki validitas yang baik.
Adapun nilai discriminant validity yang terwakili AVE menunjukkan bahwa konstruk eksogen FRQU, POMI, ETVA, INCO masing-masing bernilai 0,6002; 0,$6334 ; \quad 0,7229 ; \quad$ serta 0,8240 , yang mengindikasikan bahwa setiap indikator refleksif mampu merepresentasikan konstruknya. Selanjutnya nilai AVE pada konstruk endogen CRAT sebesar 0,6194 yang bermakna bahwa indikator refleksif mampu merepresentasikan konstruknya. Hasil uji validitas ditampilkan dalam Tabel 3 dan secara grafis pada Gambar 2. Perhitungan melalui Menu bootstrapping menunjukkan hasil bahwa seluruh indikator dapat merefleksikan konstruk FRQU, POMI, ETVA, INCO dan CRAT secara signifikan. 
Hal ini tercermin pada nilai t-statistik indikator refleksif yang menunjukkan angka lebih besar dari ambang nilai 2,58 (t-tabel) pada p-value lebih kecil dari 0,01, sebagaimana tersaji dalam Tabel 3.

Hasil uji reliabilitas juga dapat disimak pada Tabel 3. Hasil uji reliabilitas dari seluruh konstruk menampilkan nilai composite reliability untuk FRQU sebesar
0,9119; POMI sebesar 0,9392; ETVA sebesar 0,9538; INCO sebesar 0,9492, serta CRAT dengan nilai 0,9279. Seluruh nilai composite reliability melebihi ambang nilai 0,70 . Hal ini sekaligus menunjukkan bahwa seluruh konstruk pada penelitian ini memiliki Reliabilitas yang baik.

Tabel 3

Tabulasi Hasil Uji Validitas, Uji Reliabilitas, Signifikansi Indikator, $\mathbf{R}^{2}$, dan $\mathbf{Q}^{2}$

\begin{tabular}{|c|c|c|c|c|c|c|c|}
\hline $\begin{array}{c}\text { Konstruk } \\
\text { (Variabel Laten) }\end{array}$ & $\begin{array}{c}\text { Kode } \\
\text { Indikator }\end{array}$ & $\begin{array}{l}\text { Loading } \\
\text { Factor }\end{array}$ & AVE & $\begin{array}{l}\text { Comp. } \\
\text { Reliab. }\end{array}$ & $\begin{array}{l}\text { t-Stat**** } \\
\text { Indikator }\end{array}$ & $\mathbf{R}^{2}$ & $\mathbf{Q}^{2}$ \\
\hline $\begin{array}{l}\text { FINANCIAL } \\
\text { REPORT } \\
\text { QUALITY } \\
\text { (FRQU) }\end{array}$ & $\begin{array}{l}\text { FRQU1 } \\
\text { FRQU2 } \\
\text { FRQU3 } \\
\text { FRQU4 } \\
\text { FRQU5 } \\
\text { FRQU6 } \\
\text { FRQU7 }\end{array}$ & $\begin{array}{l}0,8277 \\
0,8377 \\
0,8620 \\
0,8097 \\
0,5711 \\
0,7785 \\
0,6954 \\
\end{array}$ & 0,6002 & 0,9119 & $\begin{array}{c}18,5350 \\
18,9757 \\
20,1502 \\
16,7586 \\
6,4458 \\
16,4100 \\
10,0545\end{array}$ & - & - \\
\hline $\begin{array}{l}\text { PERCEIVED OF } \\
\text { MANAGEMENT'S } \\
\text { INCENTIVES } \\
\text { (POMI) }\end{array}$ & $\begin{array}{l}\text { POMI1 } \\
\text { POMI2 } \\
\text { POMI3 } \\
\text { POMI4 } \\
\text { POMI5 } \\
\text { POMI6 } \\
\text { POMI7 } \\
\text { POMI8 } \\
\text { POMI9 }\end{array}$ & $\begin{array}{l}0,8118 \\
0,8893 \\
0,8177 \\
0,8571 \\
0,8307 \\
0,7522 \\
0,7456 \\
0,6435 \\
0,7883 \\
\end{array}$ & 0,6334 & 0,9392 & $\begin{array}{c}24,7036 \\
37,6122 \\
15,9518 \\
22,1982 \\
19,7165 \\
11,6375 \\
9,5526 \\
6,0913 \\
10,2215\end{array}$ & - & - \\
\hline $\begin{array}{l}\text { ETHICAL VALUE } \\
\text { (ETVA) }\end{array}$ & $\begin{array}{l}\text { ETVA1 } \\
\text { ETVA2 } \\
\text { ETVA3 } \\
\text { ETVA4 } \\
\text { ETVA5 } \\
\text { ETVA6 } \\
\text { ETVA7 } \\
\text { ETVA8 }\end{array}$ & $\begin{array}{l}0,6325 \\
0,8916 \\
0,8977 \\
0,8603 \\
0,8614 \\
0,9170 \\
0,8042 \\
0,9011 \\
\end{array}$ & 0,7229 & 0,9538 & $\begin{array}{c}8,5699 \\
30,6000 \\
24,3260 \\
20,0462 \\
22,3330 \\
38,5406 \\
17,3420 \\
35,3615\end{array}$ & - & - \\
\hline $\begin{array}{l}\text { INTERNAL } \\
\text { CONTROL } \\
\text { (INCO) }\end{array}$ & $\begin{array}{l}\text { INCO1 } \\
\text { INCO2 } \\
\text { INCO3 } \\
\text { INCO4 }\end{array}$ & $\begin{array}{l}0,8232 \\
0,9432 \\
0,9415 \\
0,9177\end{array}$ & 0,8240 & 0,9492 & $\begin{array}{l}12,6801 \\
36,3160 \\
53,1284 \\
27,5064\end{array}$ & - & - \\
\hline $\begin{array}{l}\text { ATTITUDES } \\
\text { TOWARDS } \\
\text { CREATIVE } \\
\text { ACCOUNTING } \\
\text { (CRAT) }\end{array}$ & $\begin{array}{l}\text { CRAT1 } \\
\text { CRAT2 } \\
\text { CRAT3 } \\
\text { CRAT4 } \\
\text { CRAT5 } \\
\text { CRAT6 } \\
\text { CRAT7 } \\
\text { CRAT8 }\end{array}$ & $\begin{array}{l}0,7705 \\
0,8906 \\
0,8634 \\
0,7491 \\
0,6849 \\
0,8383 \\
0,8257 \\
0,6387\end{array}$ & 0,6194 & 0,9279 & $\begin{array}{c}10,6159 \\
35,5829 \\
26,3250 \\
10,4866 \\
7,6919 \\
19,3877 \\
19,0416 \\
8,1004\end{array}$ & 0,6929 & 0,4075 \\
\hline
\end{tabular}

Note: $* * *$ sig. pada $\mathrm{p}<0,01$

Hasil Uji Model Struktural (Inner Model

Test)
Tabel 3 dan Gambar 2 menampilkan nilai Koefisien Determinasi $\left(\mathrm{R}^{2}\right)$ dari 
konstruk endogen CRAT. Olahan data dengan menu PLS Algoritma memberikan nilai $\mathrm{R}^{2}$ untuk CRAT sebesar $69,29 \%$. Hasil tersebut mengindikasikan bahwa konstruk eksogen FRQU, POMI, ETVA dan INCO mampu menjelaskan variabilitas konstruk endogen CRAT dengan kecenderungan substansial $\left(\mathrm{R}^{2}\right.$ melebihi ambang nilai 0,50 hampir mendekati ambang nilai 0,75). Perhitungan Stone-Geisser's $\mathbf{Q}^{2}$ value dengan menu blindfolding pada aplikasi SmartPls ${ }^{\circledR}$ v.2 - dapat disimak pada Tabel 3menunjukkan bahwa konstruk endogen CRAT memiliki $\mathrm{Q}^{2}$ sebesar 0,4075. Oleh karena nilai $\mathrm{Q}^{2}$ lebih besar dari nol, maka hal tersebut mengindikasikan konstruk eksogen FRQU, POMI, ETVA, serta INCO secara statistik terbukti memiliki relevansi prediktif terhadap konstruk endogen CRAT.

Seluruh hasil perhitungan $\mathrm{F}^{2}$ dari konstruk eksogen FRQU, POMI, ETVA, dan INCO terhadap konstruk endogen CRAT dapat disimak pada Tabel 4. Hasil uji $\mathrm{F}^{2}$ dari konstruk eksogen FRQU, ETVA, dan INCO terhadap konstruk endogen CRAT masingmasing sebesar 0,$0922 ; 0,0358 ; 0,0694$ yang mengindikasikan bahwa konstruk eksogen FRQU, ETVA, dan INCO memiliki effect cenderung medium (karena melebihi ambang nilai 0,02) terhadap konstruk endogen CRAT. Sedangkan hasil $\mathrm{F}^{2}$ dari konstruk eksogen POMI terhadap konstruk endogen CRAT adalah sebear 0,3051 yang mengindikasikan bahwa konstruk eksogen POMI memiliki effect cenderung besar (karena melebihi ambang nilai 0,15) terhadap konstruk endogen CRAT. Empat path coefficient yang diperoleh dalam inner model test membentuk persamaan struktural sebagai berikut: CRAT $=0,2734$ FRQU + 0,4084 POMI + 0,1687 ETVA + 0,1787 INCO + $\zeta$. Nilai path coefficient konstruk eksogen terhadap

konstruk endogen beserta tingkat signifikansinya dapat disimak pada Tabel 5.

Tabel 4

Tabulasi Hasil Uji $\mathbf{F}^{2}$ (effect size) Konstruk Eksogen terhadap Konstruk Endogen CRAT

\begin{tabular}{cccccc}
\hline $\begin{array}{c}\text { K o n s t r u k } \\
\text { E k s o g n n }\end{array}$ & (=A) & $(=\mathbf{B})$ & $\mathbf{C = A}-\mathbf{B}$ & $\mathbf{D}=\mathbf{1}-\mathbf{A}$ & $\mathbf{F}^{2}=$ \\
\hline FRQU & 0,6929 & 0,6646 & 0,0283 & 0,3071 & 0,0922 \\
POMI & 0,6929 & 0,5992 & 0,0937 & 0,3071 & 0,3051 \\
ETVA & 0,6929 & 0,6819 & 0,0110 & 0,3071 & 0,0358 \\
INCO & 0,6929 & 0,6716 & 0,0213 & 0,3071 & 0,0694 \\
\hline
\end{tabular}

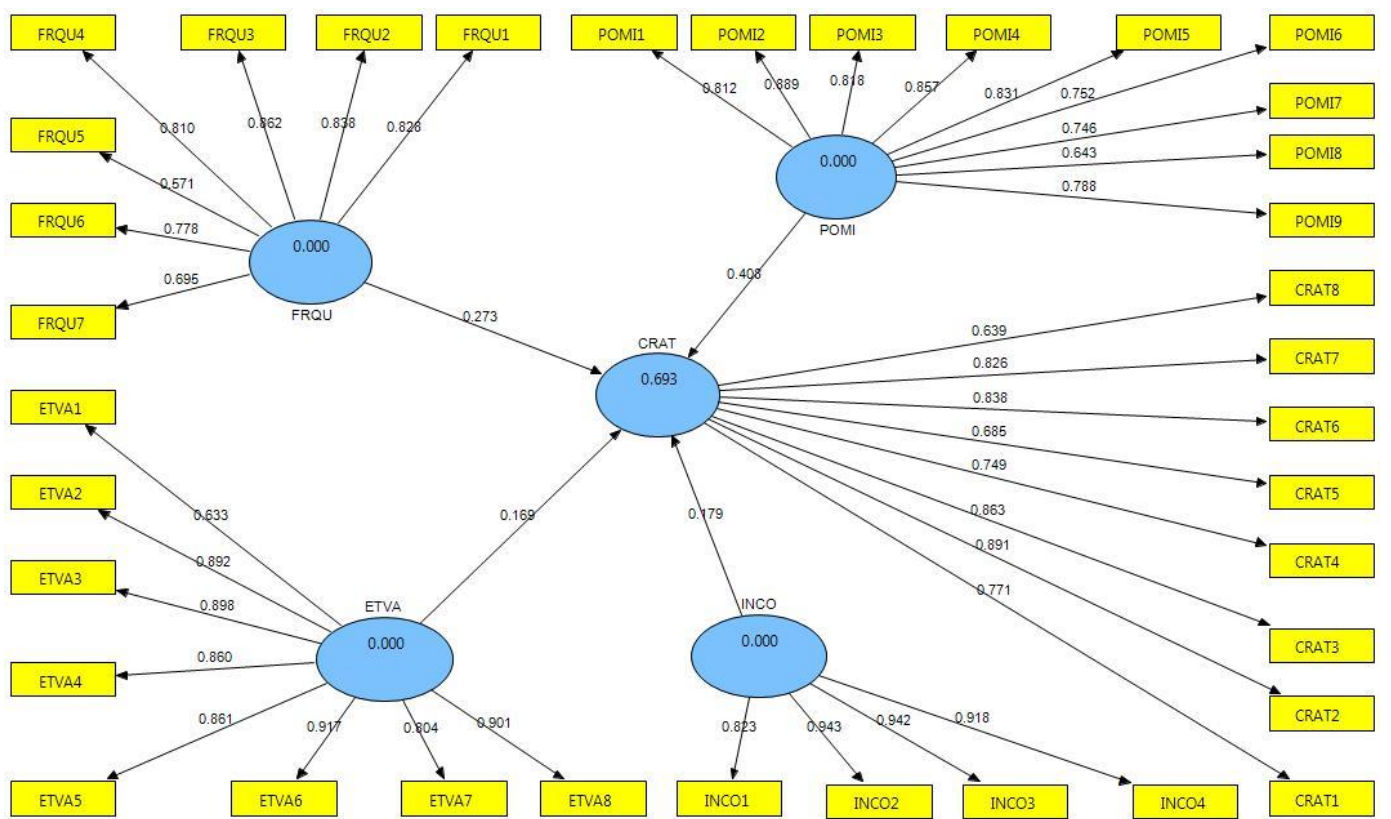


Gambar 2.

Output Menu PLS Algoritma (dengan menggunakan SmartPLS ${ }^{\circledR}$ v.2)

Tabel 5

Tabulasi Rangkuman Hasil Uji Hipotesis

\begin{tabular}{|c|c|c|c|c|}
\hline Hipotesis & $\begin{array}{l}\text { Kausal Prediktif } \\
\text { antarkonstruk }\end{array}$ & $\begin{array}{c}\text { Path Coeff. } \\
()\end{array}$ & t-Stat & $\underset{\text { Hipotesis }}{\text { Simpulan Uji }}$ \\
\hline $\mathbf{H _ { 1 }}$ & FRQU $\rightarrow$ CRAT & 0,2734 & $2,6587 * * *$ & Menolak Ho \\
\hline $\mathbf{H}_{2}$ & $\mathrm{POMI} \rightarrow \mathrm{CRAT}$ & 0,4084 & $4,2292 * * *$ & Menolak Ho \\
\hline $\mathbf{H}_{3}$ & ETVA $\rightarrow$ CRAT & 0,1687 & $1,7094 *$ & Menolak Ho \\
\hline $\mathbf{H}_{4}$ & $\mathrm{INCO} \rightarrow \mathrm{CRAT}$ & 0,1787 & $2,2913 * *$ & Menolak Ho \\
\hline
\end{tabular}

\section{Pembahasan Hasil Uji Hipotesis Satu $\left(\mathrm{H}_{1}\right)$}

Hipotesis Satu $\left(\mathrm{H}_{1}\right)$ menyatakan bahwa perspektif akuntan publik tentang financial report quality (FRQU) berpengaruh positif terhadap sikap akuntan publik atas praktek creative accounting yang dilakukan oleh pihak klien (CRAT). Secara statistik, penelitian ini berhasil menolak Ho. Tabel 5 dan Gambar 2 menunjukkan olahan dari menu PLS Algoritma berupa nilai path

coefficient sebesar 0,2734 yang mencerminkan bahwa hubungan kausal prediktif antar konstruk bersifat positif. Signifikansi dari path coefficient ditunjukkan oleh olahan menu bootstrapping berupa nilai t-statistik sebesar 2,6587 yang signifikan pada $p$-value lebih kecil dari 0,01 , yang dapat disimak pula pada Tabel 5. Hasil ini konsisten dengan penelitian yang dilakukan oleh Rabin (2005), Tasios dan Bekiaris (2012), dan Olaganju (2011). Rabin (2005) bahkan menemukan bahwa atribut relevansi, realibilitas dan dapat dipahami (understandability) mempunyai pengaruh signifikan terhadap sikap akuntan publik atas creative accounting.

Hasil uji $\mathrm{H}_{1}$ menunjukkan bahwa kualitas laporan keuangan mempunyai pengaruh positif secara signifikan terhadap sikap akuntan publik atas praktek creative accounting. Hal ini disebabkan karena pemahaman pemakai laporan keuangan adalah berdasarkan pada karakteristik kualitatif yang berperan dalam penyediaan laporan keuangan yang berguna (Van Beest, et al. 2009). Oleh karena itu, sikap akuntan publik juga didasarkan pada evaluasi akuntan publik atas kualitas laporan keuangan yang tersaji dalam laporan keuangan. Menurut
Tasios dan Bekiaris (2012), kualitas pelaporan keuangan merupakan prasyarat utama bagi fungsi efektif dari perekonomian. Akuntan publik percaya bahwa faktor utama yang membuat kualitas laporan keuangan menjadi buruk adalah adanya earning management, tata kelola perusahaan yang buruk, adanya penyimpangan terhadap

standar akuntansi, tidak cukupnya pengawasan atau supervisi dari otoritas publik dan adanya kepemilikan keluarga (Tasios dan Bekiaris, 2012). Akuntan publik melakukan audit dengan melihat karakteristik kualitatif yang ada di dalam laporan keuangan yaitu: dapat dipahami, relevan, dapat dipercaya dan dapat dibandingkan. Karakteristik kualitatif yang terdapat dalam laporan keuangan dapat mencerminkan keadaan yang sedang terjadi dalam perusahaan. Dengan melihat karakteristik kualitatif tersebut, maka akuntan publik

berpotensi mengungkapkan terjadinya praktek creative accounting yang dilakukan oleh manajemen perusahaan.

\section{Pembahasan Hasil Uji Hipotesis Dua $\left(\mathbf{H}_{2}\right)$}

Hipotesis Dua $\left(\mathrm{H}_{2}\right)$ menyatakan bahwa perspektif akuntan publik tentang management's incentives (POMI) dalam memanipulasi laba berpengaruh positif terhadap sikap akuntan publik atas praktek creative accounting yang dilakukan oleh pihak klien (CRAT). Secara statistik, penelitian ini berhasil menolak Ho. Tabel 5 dan Gambar 2 menunjukkan olahan dari menu PLS Algoritma berupa nilai path

coefficient sebesar 0,4084 yang mencerminkan bahwa hubungan kausal prediktif antar konstruk bersifat positif. 
Signifikansi dari path coefficient ditunjukkan oleh olahan menu bootstrapping berupa nilai t-statistik sebesar 4,2292 yang signifikan pada $p$-value lebih kecil dari 0,01 , dan dapat disimak pada Tabel 5. Hasil penelitian ini konsisten dengan penelitian Nassirzadeh, et al. (2012) dan Matsumoto (2002), tetapi tidak konsisten dengan penelitian Rabin (2005).

Hasil uji $\mathrm{H}_{2}$ menunjukkan bahwa persepsi mengenai insentif manajemen berpengaruh positif secara signifikan terhadap sikap akuntan publik atas praktek creative accounting. Dalam melakukan audit, akuntan publik tentunya memperhatikan faktor-faktor yang mempengaruhi pihak manajemen/ pembuat laporan keuangan menggunakan creative accounting. Penelitian Nassirzadeh, et al. (2012) menunjukkan bahwa ukuran perusahaan mempengaruhi terjadinya earning management. Ukuran perusahaan yang besar akan menimbulkan resiko terjadinya earning management yang lebih tinggi dibandingkan ukuran perusahaan yang kecil. Penelitian Matsumoto (2002)

menunjukkan bahwa kepemilikan institusional mempengaruhi terjadinya earning management. Kepemilikan institusional yang tinggi akan menimbulkan resiko terjadinya earning management yang lebih tinggi pula. Faktor-faktor yang mempengaruhi pembuat laporan keuangan menggunakan creative accounting tersebut memberikan pengaruh terhadap sikap akuntan publik atas praktek creative accounting karena jika akuntan publik memahami faktorfaktor apa saja yang mendorong terjadinya praktek creative accounting maka akuntan publik akan melibatkan pemahaman tersebut dalam pemberian opini audit.

\section{Pembahasan Hasil Uji Hipotesis Tiga $\left(\mathrm{H}_{3}\right)$}

Hipotesis Tiga $\left(\mathrm{H}_{3}\right)$ menyatakan bahwa perspektif akuntan publik tentang ethical values (ETVA) berpengaruh positif terhadap sikap akuntan publik atas praktek creative accounting yang dilakukan oleh pihak klien (CRAT). Secara statistik, penelitian ini berhasil menolak Ho. Tabel 5 dan Gambar 2 menunjukkan olahan dari menu PLS Algoritma berupa nilai path coefficient sebesar 0,1687 yang mencerminkan bahwa hubungan kausal prediktif antar konstruk bersifat positif. Signifikansi dari path coefficient ditunjukkan oleh olahan menu bootstrapping berupa nilai t-statistik sebesar 1,7094 yang signifikan pada $p$-value lebih kecil dari 0,1 , dan tersaji pada Tabel 5. Hasil ini konsisten dengan hasil penelitian Al Momani dan Obeidat (2013), Gul, F.A, et al. (2003), Wier, Benson, et al. (2008) dan Elias oleh olahan menu bootstrapping berupa nilai t-statistik sebesar 2,2913 yang signifikan pada $p$-value lebih kecil dari 0,05 , dan dapat disimak pada Tabel 5. Hasil ini konsisten

(2002). Tetapi tidak konsisten dengan penelitian Rabin (2005) dan Bennie dan Pflugrath (2009).

Hasil uji $\mathrm{H}_{3}$ menunjukkan bahwa ethical values memiliki pengaruh positif secara signifikan terhadap sikap akuntan publik atas praktek creative accounting. Hal ini bisa terjadi karena aturan perilaku merupakan standar minimum yang harus dilaksanakan (Al Momani dan Obeidat, 2013). Sikap akuntan publik untuk mendukung atau tidak atas praktek creative accounting tidak hanya dipengaruhi oleh hukum yang berlaku tetapi juga dipengaruhi oleh pemahaman akuntan publik atas nilainilai etis. Kesadaran yang tinggi akan ethical values menyebabkan akuntan publik berhatihati untuk mendukung ataupun tidak atas praktek creative accounting. Dengan kata lain, ethical values yang dijunjung tinggi akan memperkuat sikap akuntan publik untuk tidak membiarkan berlangsungnya praktek creative accounting yang dilakukan oleh pihak klien, yang terindikasi melanggar standar dan/atau menyimpang dari prosedur.

\section{Pembahasan Hasil Uji Hipotesis Empat ( $\left.\mathrm{H}_{4}\right)$}

Hipotesis Empat $\left(\mathrm{H}_{4}\right)$ menyatakan bahwa perspektif akuntan publik tentang internal control (INCO) berpengaruh positif terhadap sikap akuntan publik atas praktek creative accounting yang dilakukan oleh pihak klien (CRAT). Secara statistik, penelitian ini berhasil menolak Ho. Tabel 5 dan Gambar 2 menunjukkan olahan dari menu PLS Algoritma berupa nilai path 
dengan hasil penelitian Balaciu, et al. (2012), Arel, et al. (2005) dan O'Leary, et al. (2006). Tetapi tidak konsisten dengan penelitian $\mathrm{Al}$ Sawalqa dan Qtish (2012).

Hasil uji $\mathrm{H}_{4}$ menunjukkan bahwa pengendalian internal mempunyai pengaruh positif secara signifikan terhadap sikap akuntan publik atas praktek creative accounting. Selaras dengan Balaciu, et al. (2012), bahwa pengendalian internal yang baik mencegah lebih banyak kecurangan dibandingkan potensi temuan oleh akuntan publik. Dalam melakukan audit, akuntan publik akan memperhatikan terlebih dahulu apakah pengendalian internal yang dimiliki oleh suatu perusahaan lemah atau kuat.

Pemahaman akuntan publik atas pengendalian internal akan digunakan dalam melakukan pengujian substantif dan mengidentifikasi salah saji yang material. Jadi, akuntan publik melakukan pemeriksaan berdasarkan pengendalian internal yang diterapkan dalam perusahaan. Adanya pengendalian internal yang memadai akan memperkuat persepsi akuntan publik bahwa penugasan audit relatif mampu mengidentifikasi kemungkinan terjadinya praktek creative accounting oleh pihak klien, yang menyalahi prosedur dan/atau menyimpang dari standar.

\section{SIMPULAN DAN SARAN}

Hasil uji hipotesis $\mathrm{H}_{1}, \mathrm{H}_{2}, \mathrm{H}_{3}$, dan $\mathrm{H}_{4}$ menunjukkan bahwa $\mathbf{H}_{\mathbf{0}}$ ditolak, dengan demikian hasil penelitian ini secara empiris dapat memprediksi bahwa konstruk eksogen financial report quality, perceived of management's incentives, ethical value, dan internal control masing-masing memiliki pengaruh positif secara signifikan terhadap konstruk endogen sikap akuntan publik atas praktek creative accounting yang dilakukan oleh pihak klien. Hasil temuan dalam penelitian ini sekaligus menunjukkan bahwa Masalah maupun Tujuan penelitian ini telah terverifikasi. Seberapa kuat hubungan kausal antar konstruk eksogen (FRQU, POMI, ETVA, dan INCO) terhadap konstruk

endogen (CRAT) terjawab dengan perhitungan $\mathrm{F}^{2}$ dimana konstruk eksogen FRQU, ETVA, dan INCO memiliki effect cenderung medium, sedangkan konstruk eksogen POMI memiliki effect cenderung besar. Daya prediksi hubungan kausal tercermin dari nilai Stones-Geisser's $Q^{2}$ value. Oleh karena nilai $\mathrm{Q}^{2}$ lebih besar dari nol, maka hal tersebut mengindikasikan konstruk eksogen FRQU, POMI, ETVA, dan INCO secara statistik terbukti memiliki relevansi prediktif terhadap konstruk endogen CRAT.

Hasil penelitian ini setidaknya dapat menyuguhkan rujukan bagi praktisi KAP bahwa akuntan publik diharapkan senantiasa mempertimbangkan apakah informasi akuntansi yang disajikan dalam laporan keuangan telah relevan, andal, komparabel, dan dapat dimengerti pada saat menyusun opini audit mengenai kewajaran laporan keuangan pihak klien. Kendati praktek creative accounting tidak mungkin dihindari pada laporan keuangan klien, namun sikap akuntan publik yang menjunjung tinggi nilainilai etis maupun aspek profesionalitas akan memperkokoh perilaku kehati-hatian akuntan publik pada saat menerima penugasan audit dari pihak klien, khususnya pada aktivitas pemberian opini audit.Sejumlah hal yang menjadi limitasi dalam penelitian ini adalah: a) data sampel yang dapat digunakan relatif sedikit $(\mathrm{N}=70$, useful response-rate hanya $35 \%)$; b) mungkin saja data tidak normal, sebagai imbas dari penerapan metode PLSSEM yang tidak mensyaratkan dilakukannya uji normalitas; c) tidak tertutup kemungkinan bahwa responden tidak mengisi kuesioner dengan jujur; d) responden hanya berada pada lokasi Jakarta saja; e) responden hanya berasal dari sektor privat. Hasil penelitian ini diharapkan memberikan sumbangsih dan kontribusi bagi kalangan peneliti akuntansi bidang pengauditan, etika, maupun keperilakuan di Indonesia. State of art dari penelitian ini berpotensi menyajikan kebaharuan dalam topik penelitian akuntansi. Penelitian mendatang relatif masih sangat memungkinkan dilakukan baik melalui replikasi dan/ataupun adaptasi. Penelitian berikutnya seyogyanya dapat menghadirkan temuan dengan subyek penelitian yang berasal dari sektor publik atau pemerintah. Apabila memungkinkan penelitian dengan topik sejenis dengan membandingkan sikap akuntan di sektor privat dengan akuntan di sektor publik terkait dengan praktek creative accounting 


\section{DAFTAR RUJUKAN}

Alexander, A., dan Archer, S. 2003. On economic reality, representational faithfulness and the true and fair override. Accounting and business research, 33(1): 3-17.

Al Momani, A.M., dan Obeidat, I.M. 2013. The effect of auditors' ethics on their detection of creative accounting practices: a field study. International journal of business and management 8 (13): 118136.

Al Sawalqa, F. dan Qtish, A. 2012. Internal control and audit program effectiveness: empirical evidence from jordan. International research business 5(9): 128137.

Arel, B., Kaplan, S.E., dan O' Donnel, E. 2006. Halo effects during internal control evaluation: the influence of management self-assessment on auditor judgement. Proceeding of mid year meeting of the auditing section of the

american accounting association, January: 1-30.

Arens,, A.A., Elder, R.J., dan Beasley, M.S. 2012. Auditing and assurance services: an integrated approach $14^{\text {th }}$ ed. New Jersey: Pearson Education, Inc.

Balaciu, D.E., Bogdan, V., Meşter, I.T., dan Gherai, D. 2012. Empirical evidences of romanian auditors' behavior regarding creative accounting practices. Accounting and management information systems 11(2): 213-238.

Bennie, N.M., dan Pflugrath, G. 2009. Strength of an accounting firm's ethical environment and the quality of auditors' judgments. Journal of business ethics 87: 237-253.

Bowen, R. M., Johnson, M. F., Shevlin, T., dan Shores, D. 1992. Determinants of the timing of quarterly earnings announcement. Journal of accounting, auditing and finance 7 (4): 395422.
Elias, R.Z. 2002. Determinant of earnings management ethics among accountants. Journal of business ethics 40(1): 33-45.

Ferdinand, A. 2014. Structural equation modeling dalam penelitian manajemen: aplikasi model-model rumit dalam penelitian untuk skripsi, tesis, dan disertasi doktor (edisi 5). Semarang: Badan Penerbit Undip.

Ghozali, I. 2011. Structural equation modeling metode alternatif dengan partial least square (edisi ketiga). Semarang: Badan Penerbit Undip.

Gul, F.A, Ng, A.Y., dan Tong, M.Y.J.W. 2003. Chinese auditors' ethical behavior in an audit conflict situation. Journal of business ethics 42(4): 379-392.

Hair, J.F., Hult, G.T.M., Ringle, C.M., dan Sarstedt, M. 2014. A primer on partial least squares structural equation modeling (pls-sem). SAGE Publication, Inc.

Idris, A.A., Kehinde, J.S., Ajemunigbohun, S.S.A., dan Gabriel, J. M.O. 2012. The nature, techniques and prevention of creative accounting: empirical evidence from nigeria. Ecanadian journal of accounting and finance 1(1): 26-31.

International Accounting Standards Board (IASB). 2013. International financial reporting standard, issued at 1 january. United Kingdom: IFRS Foundation Department.

International Auditing and Assurance Standards Board (IAASB). 2015. Handbook of international quality control, auditing, review, other

assurance, and related services pronouncements, volume 1. New York: International Federation of Accountants.

Jensen, M.C., dan Meckling, W.H. 1976. Theory of the firm: managerial 
behavior, agency costs and ownership structure. Journal of financial economics 3(4): 305-360.

Jogiyanto. 2010. Metodologi penelitian bisnis: salah kaprah dan pengalaman pengalaman (Edisi Pertama). Yogjakarta: BPFE.

Jones, M. 2011. Creative accounting, fraud and international accounting scandals. West Sussex, England: John Wiley \& Sons, Inc.

Laplume, A.O., Sonpar, K., dan Litz, R.A. 2008. Stakeholder theory: reviewing a theory that moves us. Journal of management 34 (6): 1152-1189.

Lubatkin, M.H., Lane, P.J., Collin, S., dan Very, P. 2005. Origins of corporate governance in the usa, sweden and france. Organization studies 26(6): 867-888.

Matsumoto, D.A. 2002. Management's incentives to avoid negative earning surprises. The accounting review 77(3): 483-514.

McBride, D.M. 2010. The process of research in psychology. Thousand Oaks, C.A.: Sage Publications.

Mulford, C.W., dan Comiskey, E.E. 2002. The financial numbers game: detecting creative accounting practices. New York: John Wiley \& Sons, Inc.

Nassirzadeh, F., Salehi, M., dan Alaei, S.M. 2012. A study of the factors affecting earning management: iranian overview. Science series data report 4(2): 22-27.

Olagunju, A. 2011. An empirical analysis of the impact of auditors independence on the credibility of financial statement in nigeria. Research journal of finance and accounting 2(3): 82-98.

O'Leary, C., Iselin, E., dan Divesh, S. 2006. The relative effects of elements of internal control on auditors' evaluations of internal controls. Pacific accounting review (nz) 18(2): 68-95.

Rabin, C.E. 2005. Determinants of auditors' attitudes towards creative accounting. Meditari accountancy research 13(2): $67-$ 88.

Rani, P., Hussain, F.F., dan Chand, P.V. 2013. Managerial incentives for earnings management among listed firms: evidence from fiji. Global journal of business research 7(1): 21-31.

Richardson, V. J. 2000. Information asymmetry and earnings management: some evidence. Review of quantitative finance and accounting 15 (4): 325-347.

Salome, E.N., Ifeanyi, O.M., Ezemoyih, C.M., dan Echezonachi, O.E. 2012. The effect of accounting on the job performance of accountants (auditors) in reporting financial statement in nigeria. Kuwait chapter of arabian journal of business and management review 1(9): 1-30.

Tasios, S., dan Bekiaris, M. 2012. Auditor's perceptions of financial reporting quality: the case of greece. International journal of accounting and financial reporting 2(1): 57-74.

Van Beest, F., Braam, G., dan Boelens, S.

2009. Quality of financial reporting: measuring qualitative characteristics. Nice working paper 09-108 (april): 1-40.

Vanderstoep, S.W., dan Johnston, D.D. 2009. Research methods for everyday life: blending qualitative and quantitative approaches. San Fransisco: John Wiley \& Sons, Inc.

Vladu, A.B., dan Matis, D. 2010. Corporate governance and creative accounting: two concepts strongly connected? Some intersting insights highlighted by constructing the internal history of a literature. Annales universitatis apulensis series oeconomica 12(1): 332-346.

Wier, B. 2008. The effect of ethical orientation and professional commitmenton earnings management behavior. Journal of business ethics 83: 419-434.

Winston, C. C. K., dan Sharp, D. 2005. Power and international accounting standard setting: evidence from segment reporting and intangible assets projects. Accounting, auditing and accountability journal 18(1): 74-99. 
Journal of Business Administration Volume1, Nomor2,September 2017, hlm. 319-336

Yadav, B. 2013. Creative accounting: amanagement december 1(5):

literature review. The sij transactions on $\quad$ (ifbm), 181-193 industrial, financial \& business 